\title{
Olfactory Receptor Cell
}

National Cancer Institute

\section{Source}

National Cancer Institute. Olfactory Receptor Cell. NCI Thesaurus. Code C13151.

A specialized, fusiform nerve cell with a large nucleus, embedded among the epithelial cells in the mucous membrane of the nose; it carries impulses from the olfactory receptors to the glomeruli in the olfactory bulb. 